\title{
SOCIAL INFORMATION PROCESSING DI FACEBOOK UNTUK PENGEMBANGAN KOMUNITAS SOCIAL ENTREPRENEURS
}

\author{
Diah Ajeng P, Partini, Sri Peni W \\ Universitas Gadjah Mada Yogyakarta \\ ajeng.purwani@uin-suka.ac.id
}

\begin{abstract}
This study aims to reveal how the tendency of social business players to follow the trend for growing their business. The research method used in this research is semi-ethnography approach which will be analyzed qualitatively. This research took the figures of youth social business in Yogyakarta who survived more than 3 years and use social media as one means of empowerment. In the data collection, researchers used in-depth interviews, field observations to the grouping of data through the internet. The results show that in the last three years, young social entrepreneurs more often use facebook and instagram than other social media to develop social communities and business entrepreneurs.
\end{abstract}

Keywords : digital natives, social entrepreneurs, empowerment

\section{PENDAHULUAN}

Tahun 2017, ASEAN genap berusia 50 tahun. Di tahun 2017 pula ASEAN plus Three bertepatan dengan ulang tahun ke 20. APT adalah negara-negara ASEAN ditambah dengan Cina, Jepang, Korea. Jika dilihat dari sejarahnya, perkembangan ASEAN tidak hanya sampai perjanjian AFTA pada Januari 1992, namun merambah kepada Asean Economic Coomunity. Walaupun ekonomi merupakan hal utama yang diperhatikan namun community merupakan simbolisasi dari perlunya penyelenggaraan bisnis sosial yang sedang digiatkan oleh $G$ to $G$ (Government to Government), B to B (Busniness to Business) bahkan sampai saat ini sudah pada tataran $\mathrm{P}$ to $\mathrm{P}$ (people to People).

Salah satu indikatornya bisa dilihat dari banyaknya investor yang menanamkan investasinya kepada bisnis rintisan yang memiliki visi misi sosial. Bahkan tidak jarang investor model ini mencari anak muda yang kreatif di bidang teknologi yang tertarik dengan masalah sosial seperti gandeng tangan dan kita bisa. Perkembangan dunia bisnis tidak bisa dilepaskan dari dinamika pasar saat ini. Survey yang dilakukan tim Marketer edisi juni 2016 menyimpulkan bahwa ada tiga subkultur yang mempengaruhi dinamika dunia dan pasar saat ini yakni Youth, Women, Netizen (YWN). Ketiganya menjadi motor penggerak saat ini. YWN menunjukkan subkultur baru di era konektivitas karena mampu mempengaruhi orang lain. Mereka mampu menciptakan tren, gaya dan hal-hal yang dianggap keren oleh lingkungannya. Mereka mampu menghembuskan perubahan baik di komunitas, masyarakat maupun bangsa Indonesia ke arah yang lebih baik . 
Gambar : youth, women, and Netizen

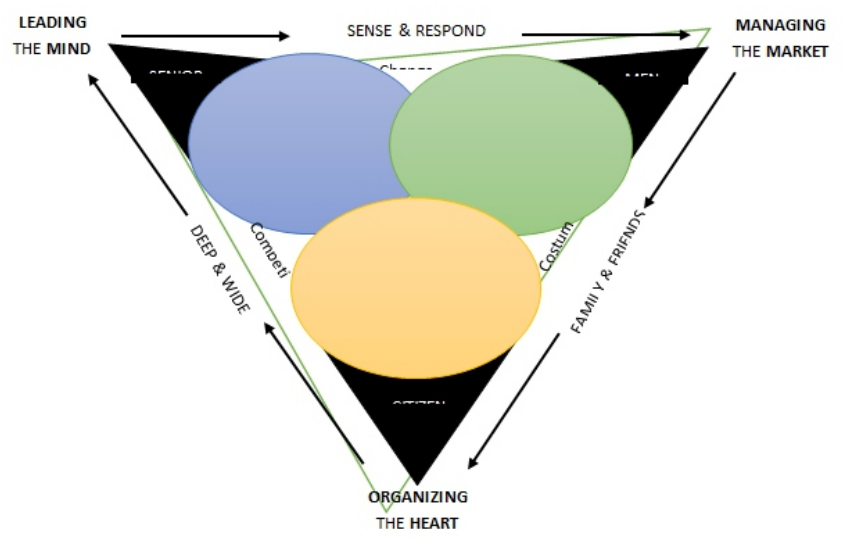

Sumber : (Kertajaya, $2017: 22$ )

Struktur yang pertama youth atau orang muda saat ini mengambil peran dan pengaruh bagi dunia dengan adanya teknologi. Sementara pada subkultur kedua yaitu women atau perempuan menjadi semakin eksis. Menurut Hermawan Kertajaya keterampilan multitasking yang merupakan DNA perempuan menjadi formula spesial di era media sosial. Mulai dari berbicara, bekerja dan memimpin bisa dilakukan di ranah online. Juga terbukti bahwa entrepreneur perempuan banyak yang lahir dengan adanya smartphone dan gadget. Sementara di subkultur ketiga yaitu netizen yang sehari-harinya selalu berinteraksi dengan internet. Mereka mengikuti tren masa kini dengan membuat koneksi, interaksi dan relasi di dunia online. Mulai dari hal-hal sederhana seperti menonton TV sudah digantikan dengan menonton di youtube.

Tokoh-tokoh penggerak juga bermunculan di era digital ini. Entrepreneur seperti Nadiem Makarim, bureaupreneur seperti Ridwan Kamil, knowledgepreneur seperti Hermawan Kertajaya dan masih banyak yang lainnya. Sebagai contoh, Ben selaku CMO kapan lagi network dan kawan-kawan komunitas young social entrepreneurs sangat aktif mengembangkan bidang ini. Ben menegaskan bahwa untuk menumbuhkan social entrepreneurs dibutuhkan creativepreneur agar bisa menimbulkan dampak. Kreatif untuk membikin produk, perawatan produk, sampai pemasaran. Ideafest sebagai social entrepreneurship juga berusaha menjangkau anak-anak muda yang kreatif untuk membangun negara indonesia.

Tokoh-tokohnya adalah Andy F Noya, Sara Sechan dan lain-lain. Al Fatih Timur pendiri kita bisa.com mendirikan web agar semua orang bisa punya jiwa sosial. Selain itu ada Chaerany Putri, founder gerak cepat.com yang menggawangi anak muda untuk kreatif secara sosial selama 40 hari sehingga timbul 548 ide.

Jika ditelaah lebih lanjut, salah satu faktor pemicu kelahiran berbagai komunitas terutama dibidang social entrepreneurs adalah perkembangan dunia teknologi khususnya internet. Saat ini komunitas yang ada bisa berawal dari sebuah grup pesan singkat yang kemudian menjadi komunitas untuk bertukar pikiran secara informal. Komunitas ini kemudian menjadi formal karena dilanjutkan di dunia nyata. Komunitas ini bisa terbentuk karena kesamaan hobi, tujuan, pendapat, visi dan lain-lain. Walaupun kadang ada juga komunitas yang seolah mati suri namun 
komunitas yang kemudian membesar juga banyak.

Jika kita melihat data yang ada, maka kita akan menemukan bahwa tingkat penetrasi internet dan akses internet melalui mobile phone terus bertambah setiap tahunnya di Indonesia. Menurut perusahaan riset pemasaran Nielsen, pada akhir tahun 2015 tercatat ada 92 juta user. Bahkan pada 2016, penetrasi internet di Indonesia mencapai 39\%, sedangkan akses internet melalui perangkat mobile mencapai $36 \%$.

Tingginya penggunaan internet dikalangan anak muda salah satunya disebabkan media baru khususnya media sosial. Hal ini bisa berarti bahwa ada peluang untuk berkomunikasi dengan masyarakat yang lebih luas melalui media baru terutama anak muda. Tidak hanya perusahaan yang bisa menyasar konsumen, program pemberdayaan masyarakat yang bertujuan mengedukasi juga bisa. Misalnya jika ingin menyasar para ibu maka digunakanlah facebook karena facebook bisa berdiskusi. Twitter yang cepat, youtube yang menghadirkan konten dalam bentuk video, atau lainnya.

Pemerintah juga mendorong generasi muda negeri ini untuk berwirausaha demi membuka lapangan pekerjaan. Presiden Jokowi bahkan mencanangkan program 1000 technopreneur sampai 2020. Para technopreneur yang diharapkan muncul tentunya berasal dari kalangan pemuda yang notabene penggiat dunia digital.
Bentuk keseriusan program ini adalah menjalin kerjasama dengan Google dalam bentuk edukasi IT dan pemberdayaan ekonomi digital bagi UMKM. Sejumlah kebijakan juga diambil pemerintah untuk mewujudkan upaya visi Indonesia sebagai ekonomi digital terbesar di Asia Tenggara.

\section{METODE PENELITIAN}

Penelitian ini dikategorikan sebagai penelitian kualitatif lapangan (field works/research) dengan pendekatan semi ethnografi. Penelitian semi ethnografi berusaha mendalami fenomena dari sudut pandang subyek yang diteliti sehingga di dapat pemahaman yang baik mengenai fenomena yang diteliti. Peneliti memfokuskan perhatian pada berbagai perilaku keseharian dan fenomena dinamika komunikasi yang melingkupinya sehingga dapat dipahami, ditafsirkan dan dideskripsikan apa yang sedang terjadi dan bagaimana hal tersebut dapat terjadi . Untuk itu peneliti akan berada di lapangan sehingga dapat melakukan pengamatan untuk mencermati perilaku verbal dan nonverbal subyek penelitian yang sifatnya unik dan khas dalam perilaku mencari informasi sebagaimana yang menjadi fokus dari penelitian ini .

Penelitian ini mengambil tokoh pemuda pelaku social entrepreneurs di wilayah Yogyakarta. Observasi dan wawancara mendalam digunakan sebagai tehnik pengumpulan data utama sesuai dengan tujuan penelitian yang ingin mendeskripsikan dengan 
baik dan mendalam subyek-subyek yang diteliti dalam melakukan pemberdayaan kepada masyarakat. Pencatatan (fieldnote) menjadi penting dalam pengumpulan data yang dilakukan. Peneliti juga akan menggunakan studi dokumen sebagai pengumpulan data sekunder untuk melengkapi pengetahuan, pemahaman, serta penafsiran atas fenomena selama penelitian dari awal hingga akhir.

Pengolahan serta analisis data dilakukan dengan melewati proses telaah data, reduksi, abstraksi sementara, kategorisasi, dan koding secara bersamaan dalam keseluruhan proses yang dilakukan (Moleong, 2010) Data yang ada akan diuraikan, diinterpretasi, dikomparasikan, serta ditriangulasi untuk mendapat keabsahan data yang telah dikumpulkan. Tujuannya adalah untuk memperoleh data yang lebih berkualitas untuk menunjukkan kondisi yang terjadi di lapangan.

\section{HASILDAN PEMBAHASAN}

Bisnis sosial memiliki gerak yang berbeda karena unsur sosialnya. Agar unsur sosial ini tetap berjalan maka ilmu marketing dalam menjalankan bisnis juga harus dipelajari. Dengan intensifnya teknologi internet, para start up (sebutan bagi pemain baru dan muda di dunia entrepreneur) menggunakan ini sebagai peluang bukan ancaman. Akibatnya banyak saluran komunikasi baru berbasiskan komunitas yang muncul. Komunitas offline ini terbentuk karena dipicu adanya interaksi online yang terus menerus.
Reynald Kasali seorang ahli dari UI sekaligus owner dari Rumah Perubahan mengatakan bahwa keanggotaan suku / komunitas manusia bahkan sudah tidak lagi ditandai oleh aspek regional atau kewilayahan, namun justru oleh group atau kelompokkelompok di jejaring digital seperti facebook, instagram, twitter dll. Jika direnungkan, apa yang dikatakan oleh Renald Kasali ada benarnya karena generasi masa kini lebih sering berhubungan dengan rekan di dunia maya dibandingkan dengan lingkungan sosialnya. Hal ini dapat dijadikan salah satu cara untuk masuk ke dunia anak muda. Inovasi serta terobosan yang kreatif bisa tercipta agar anak muda pun bisa terlibat dalam dunia sosial dengan memanfaatkan kecanggihan teknologi.

Dalam penelitian yang dilakukan oleh Susanto yang berjudul Media Baru dan Kebebasan Informasi dikalangan generasi pemuda, menyimpulkan bahwa media baru dengan karakternya yang fleksibel dan mudah diperoleh, menjadi akrab di tangan remaja ataupun generasi muda. Berkembangnya media baru tidak selalu berdampak negatif di kalangan anak muda. Media baru dapat berperan aktif dalam membangun kesadaran generasi muda, untuk lebih peka terhadap berbagai persoalan yang ada di sekelilingnya. Media baru yang didukung oleh kekuatan teknologi komunikasi, semakin berkembang sejalan dengan munculnya demokratisasi informasi. Bahkan dalam bingkai kebebasan berpendapat, melalui media online, generasi muda memiliki keberanian untuk mengungkapkan 
ketidaksepakatannya terhadap tindakan pemerintah, yang dinilai tidak sesuai dengan harapan masyarakat .

Penelitian lain yang membahas mengenai penggunaan media sosial meningkat seiring kemajuan teknologi yaitu penelitian Hugh Mackay mengenai New Connections, Familiar Settings : Issues in the Ethnographics Study of New Media Use at Home. Penelitian ini berusaha memahami konteks new media dan melihat aktivitas hubungan antara interaksi offline dan online.

Penelitian lain yang membahas mengenai penggunaan media sosial meningkat seiring kemajuan teknologi yaitu penelitian Hugh Mackay mengenai New Connections, Familiar Settings : Issues in the Ethnographics Study of New Media Use at Home. Penelitian ini berusaha memahami konteks new media dan melihat aktivitas hubungan antara interaksi offline dan online. Metode penelitian yang digunakan adalah ethnografi untuk memahami pola penggunaan internet dan new media. Hasil penelitian menunjukkan bahwa penggunaaan internet sangat berbeda dengan menonton televisi. Hal ini dikarenakan lebih banyak interaksi dan partisipasi bahkan produksi yang bisa terbangun melalui internet sehingga membuat pola baru dalam berinteraksi.

Konsep Social Enterpreneurship menurut rangkuman Hulgard dari berbagai referensi "Social Enterpreneurship can be defined as the creation of a social value that is produced in collaboration with people and organization from the civil society who are enganged in social innovations that usually imply and economic activity".

Definisi komprehensif Hullgard menekankan bahwa kewirausahaan sosial mempunyai empat elemen utama yakni social value, civil society, innovation, and economic activity. Penjelasannya sebagai berikut :

\section{Social Value}

Elemen ini menjadi bagian khas dalam kewirausahaan sosial yakni menciptakan manfaat sosial yang nyata bagi masyarakat dan lingkungan sekitar.

\section{Civil Society}

Elemen ini berasal dari partisipasi dan inisiatif masyarakat sipil dengan mengoptimalkan modal sosial yang ada di masyarakat.

\section{Innovation}

Elemen ini memadukan kearifan lokal dan inovasi sosial untuk memecahkan masalah sosial dengan cara-cara inovatif.

\section{Economic Activity}

Elemen ini menjadi penentu keberlangsungan kewirausahaan sosial dikarenakan antara aktivitas sosial dan aktivitas bisnis harus seimbang. Aktivitas bisnis dikembangkan untuk menjamin kemandirian dan keberlanjutan misi sosial organisasi karena adanya aktivitas ekonomi di dalamnya. 


\section{Teori Social Information Processing}

Perkembangan teori CMC yang dikemukan oleh Walther mengakui bahwa banyak bentuk-bentuk baru dari komunikasi online, seperti situs jejaring sosial (social networking) yang tidak memiliki keterbatasan seperti computer mediated communication. Social Information Processing memprediksi ketika komunikator diizinkan untuk bertukar pesan tanpa batasan temporal, maka hubungan interpersonal mereka akan sebanding dengan yang dihasilkan dalam komunikasi tatap muka. Hubungan hipersonal ini adalah hasil dari :

Pengirim secara selektif menampilkan diri untuk menciptakan kesan positif.

Penerima menafsirkan pesan dengan cara yang bias karena lebih banyak atribut karakteristik positif.

Saluran mediasi memungkinkan untuk kontrol yang lebih besar atas penciptaan pesan.

Umpan balik yang menghasilkan ramalan memenuhi kepositifan

Teori ini memberikan pandangan bahwa komunikator yang bertemu secara online memiliki prospek untuk berinteraksi secara terus-menerus.

"Anticipated future interaction refers to the process that communicators who meet online will continue to have contact in the future. Communicators who expect contact with their partner in the future are more likely to exchange more messages and develop a relationship than those who do not".

Van Dijk menyatakan bahwa model social information processing tidak terlepas dari perkembangan new media. Interaksi yang terjadi di dunia online menyebabkan jarak ruang dan waktu menjadi kecil, misalnya antara pihakpihak di daerah dan pusat, baik itu antar unit atau perseorangan. Kata-kata, teks tulisan, data, gambar dan lain sebagainya bisa diolah dalam komunikasi melalui new media .

Social Information Processing teori mengatakan bahwa manusia adalah komunikator yang kreatif, mampu menggunakan channel teks atau teks online untuk menyampaikan kehangatan yang sama dengan seperti komunikasi tatap muka.

Social Information Processing teori mengatakan bahwa komunikasi verbal bisa ditemukan saat menggunakan media online, seperti pujian, pengungkapan diri dan lain-lain. Semua itu adalah bentuk verbal dalam online. Walther mengklaim bahwa melalui selective self-presentation, orang-orang yang bertemu secara online memiliki kesempatan untuk membuat dan mempertahankan impresi yang sangat positif. Itu karena mereka dapat menulis tentang sifat, pencapaian, pemikiran, dan tindakan mereka yang paling menarik tanpa takut kontradiksi dari penampilan fisik mereka, tindakan mereka yang tidak konsisten, atau keberatan pihak ketiga yang mengetahui sisi gelap mereka. Kehadiran dunia online sekaligus memberi kesempatan kepada penggunanya 
untuk berkomunikasi tanpa harus saling hadir pada saat yang bersamaan. Walther mengacu pada beberapa bentuk Computer Mediated Communication / CMC (seperti email) sebagai saluran komunikasi. Dengan keterbatasan waktu, pengguna $\mathrm{CMC}$ bebas untuk menulis pesan yang berpusat pada orang, mengetahui bahwa penerima akan membaca pesan pada waktu yang tepat. Walther mencatat manfaat tambahan dari CMC sebagai contoh, saat pengguna mengeposkan informasi tentang apa yang ingin mereka sampaikan (upload), pengguna lain dapat menambahkan, atau bahkan mengkontraskan, informasi itu. Misalnya bagi pengguna Facebook, informasi tambahan semacam itu bisa mencakup komentar berbasis teks pada konten atau tautan ke foto dan video. Dengan kata lain, situs seperti Facebook bisa menampilkan dua jenis informasi - yang dikendalikan oleh pemilik dan berada di luar kendali langsung pemilik (Walther, 2012).

Dapat dikatakan, teori ini menjelaskan gejala dari aktor yang bermain dan diuntungkan dalam suatu fenomena virtual. Dalam pengertian inilah teori Social Information Processing yang digunakan dalam penelitian ini hendak diletakkan oleh peneliti. Teori dalam penelitian ini digunakan sebagai alat bantu menyediakan konsep yang relevan. Konsep tersebut akan digunakan untuk menafsirkan dan menganalisis data yang didapat secara virtual. Pola interaksi yang terjadi dalamnya mengaburkan batas geografi dan bisa dilakukan secara real time tanpa batasan waktu.
Hal ini senada dengan konsep global village ala McLuhan. Interaksi yang terjadi bisa sangat berkembang antara komunikan dan komunikator. Teori yang merupakan perkembangan dari teori CMC ini dipakai untuk menganalisis perkembangan interaksi online yang melebihi teori pendahulunya.

Jenis media baru sangat beragam. Nasrullah mengelompokkan media baru sebagai berikut : Situs, E-mail, Forum di Internet, Blog, Wiki, Aplikasi Pesan, Internet Broadcasting, Peer-to-Peer, The RSS, Multi User Dungeons yang bisa diakses beragam user dalam waktu bersamaan, dan Media Sosial.

Realitas yang terjadi pada generasi muda yang memanfaatkan media baru bisa dilihat dari perspektif teori ini. Interaksi yang terus menerus dikembangkan bisa menghasilkan keefektifan yang sama seperti komunikasi tatap muka. Electronic Word of Mouth (E-WOM) kerap terjadi dalam interaksi dunia online. Sebagaimana dijelaskan Baudrillard bahwa dunia virtual merupakan representasi dari alam imajinasi. Para pengguna dunia virtual bisa menjadi apa saja dan siapa saja sesuai keinginannya. Hal yang terjadi dalam dunia online bukan hanya sekedar berbicara masalah virtual tetapi sudah menjadi bagian kehidupan masyarakat (offline). Media baru yang berkembang saat ini membuatnya menarik untuk diteliti dari berbagai perspektif keilmuan. Hal ini merupakan salah satu argumen mengapa teori SIP membantu memahami bahwa new media menjadi piranti penting untuk pemberdayaan kepada generasi muda. 


\section{SOCIAL INFORMATION PROCESSING DI FACEBOOK UNTUK PENGEMBANGAN KOMUNITAS SOCIAL ENTREPRENEURS}

\section{Social Information Processing di Facebook}

Saat ini facebook memiliki penetrasi tertinggi antara semua platform sosial di Indonesia, yakni mencapai lebih dari 96 juta pengguna. Diungkapkan Waizly Darwin, SMB Lead Indonesia-Facebook, masyarakat Indonesia sering mengakses facebook sebanyak 5,7 kali dalam satu minggu dibandingkan dengan aktivitas online dan media tradisional lainnya. Hampir 50\% audience mengupdate berita melalui facebook (MIX Marcom Directory : 38). Facebook sendiri sedang mengembangkan berbagai hal untuk memanjakan penggunanya. Salah satunya adalah Deep Text, mesin pembaca teks yang dapat memahami ribuan posting setiap detik, dalam lebih dari 20 bahasa berbeda (Pambudi, 2017). Hasil penelitian menunjukkan Young social entrepreneurs menggunakan facebook sebagai salah satu media favorit untuk menyebarkan ide-ide sosial mereka.

Gambar : Media Sosial yang digunakan Young SOcial

Entrepreneurs Yogya

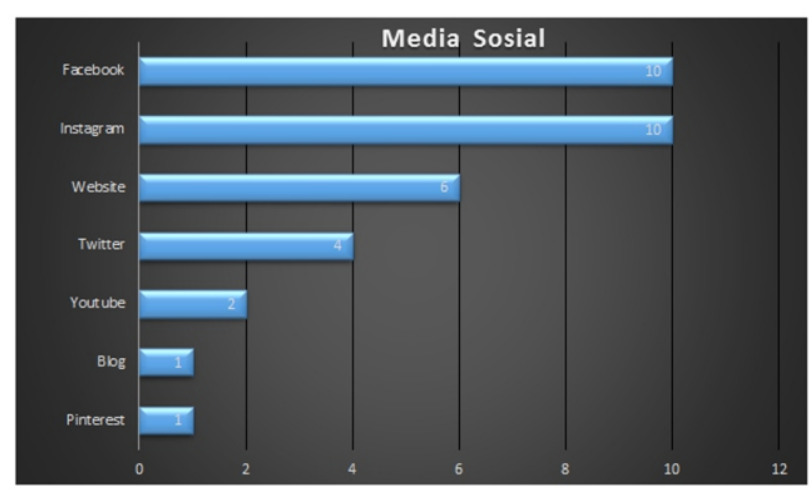

Sumber : Olah Data Peneliti
Gambar diatas menjelaskan bahwa facebook masih menjadi salah satu media sosial favorit yang digunakan oleh young social entrepreneurs. Hal ini dikarenakan berbagai macam kemudahan yang ada di facebook. Dalam wawancara juga terungkap berbagai alasan yang membuat facebook cukup populer dikalangan young social entrepreneurs.

Tabel Kelebihan Facebook untuk Media Pemberdayaan

\begin{tabular}{|l|}
\hline \multicolumn{2}{|c|}{ Kekuatan } \\
Pengguna lebih umum dan lintas usia. Sasaran lebih luas termasuk ibu-ibu Rumah \\
\hline $\begin{array}{l}\text { Pembagian pesan berantai, seperti pembagian url. Dengan adanya grup, } \\
\text { memungkinkan untuk bertukar informasi }\end{array}$ \\
\hline Karakter tidak dibatasi \\
\hline $\begin{array}{l}\text { Fitur lengkap karena jenis file apa saja bisa diupload, misalnya mp3, mp4, PDF } \\
\text { dan lain-lain. }\end{array}$ \\
\hline Dapat diakses tanpa menggunakan kuota intemet (Free data) \\
\hline Terdapat fungsi page yaitu halaman yang berfungsi seperti website \\
\hline Identitas dapat dicantumkan lebih lengkap \\
\hline Durasi Penayangan video lebih lama \\
\hline Memiliki siaran langsung berdurasi panjang \\
\hline
\end{tabular}

Sumber : Hasil Wawancara Penelitian

Berbagai kemudahan yang ditawarkan dunia online secara tidak langsung ambil bagian dalam pergeseran pola perilaku masyarakat mulai dari cara berkomunikasi, berbelanja, dan lain sebagainya. Setiap orang saat ini terutama anak muda bisa terkoneksi satu sama lain walaupun sedang rapat, macet, kuliah, jalanjalan asalkan ada internet. Hasil survey yang dilakukan pada bulan mei juni 2016 oleh perusahaan riset MARS Indonesia bekerjasama dengan majalah SWA dan Indonesia ECommerce Association (IdEA) mengungkapkan beberapa fakta mengenai perkembangan new media di Indonesia. 


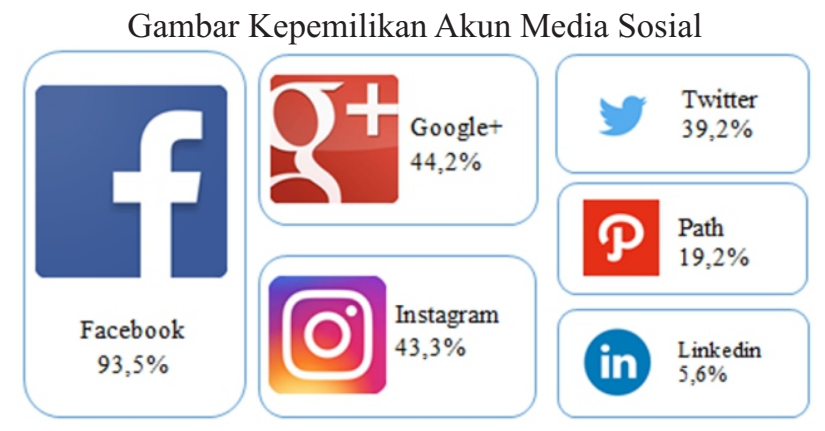

Tingkat kepemilikan akun Facebook sebagai paltform media sosial merupakan yang tertinggi (93,5\%), disusul Google $+(44,2 \%)$, Instagram (43,3\%), Twitter (39,2\%), Path (19,2\%) dan Linkedin (5,6\%)

Sumber: ("Survey Indonesia E-Commerce 2016," 2016)

Media sosial yang digunakan oleh generasi millennial juga sangat dipengaruhi oleh kebiasaan mereka mengkonsumsi internet. Hasil riset dari tim Alvara menunjukkan bahwa komsumsi internet milleninnial sangat tinggi. Mayoritas millennial masuk kategori segmen medium user, heavy user dan addicted user. Internet sudah menjadi bagian dari kehidupan mereka. Hasil riset menunjukkan bahwa ada beberapa segmen kondumen internet. Light User adalah pengguna internet dengan konsumsi internet perhari kurang dari 1 jam. Medium User adalah mereka yang mengkonsumsi internet aktif 1-3 jam sehari. Heavy User adalah yang mengkonsumsi internet secara aktif antara 4-6 jam sehari. Addicted User adalah mereka yang mengkonsumsi internet leboh dari 6 jam sehari .
Gambar Konsumsi Internet Millennial

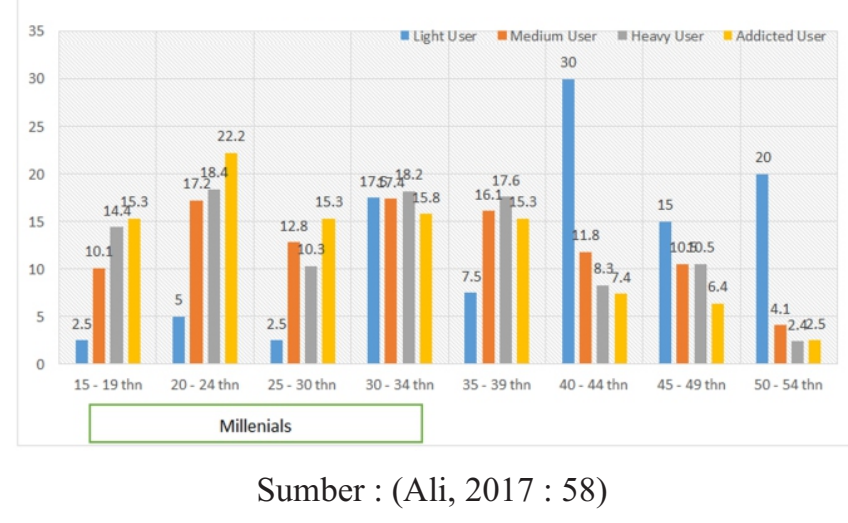

Riset kuantitatif juga dilakukan oleh tim Alvara yang menunjukkan bahwa mayoritas Milennial pernah menggunakan paling tidak lima fitur smartphone mereka. Hal yang menarik adalah penggunaan fitur media sosial, instant messenger, browser, serta kamera yang sangat tinggi. Fitur inilah yang kemudian membuat millennial memiliki pola komunikasi yang berbeda dengan generasi sebelumnya.

Kondisi inilah yang berusaha dimaksimalkan oleh para pemuda pelaku bisnis sosial. Berdasarkan hasil penelitian, media sosial yang banyak digunakan oleh para social entrepreneurs untuk melakukan pemberdayaan adalah facebook, instagram, youtube dan twitter. Masing-masing media dinilai memiliki kekuatan untuk melakukan percepatan dalam mengedukasi masyarakat di bidang sosial entrepreneurs. Penciptaan pesan positif yang selalu dipakai akan menimbulkan kesan positif juga. Berbagai foto yang diunggah, kata-kata yang ditulis dan disebarkan selalu diberikan kesan untuk memotivasi khususnya kepada para penggeraknya untuk terus berbuat kebaikan. Contoh-contoh yang diambil dibawah ini menunjukkan bahwa ada SIP di facebook. 


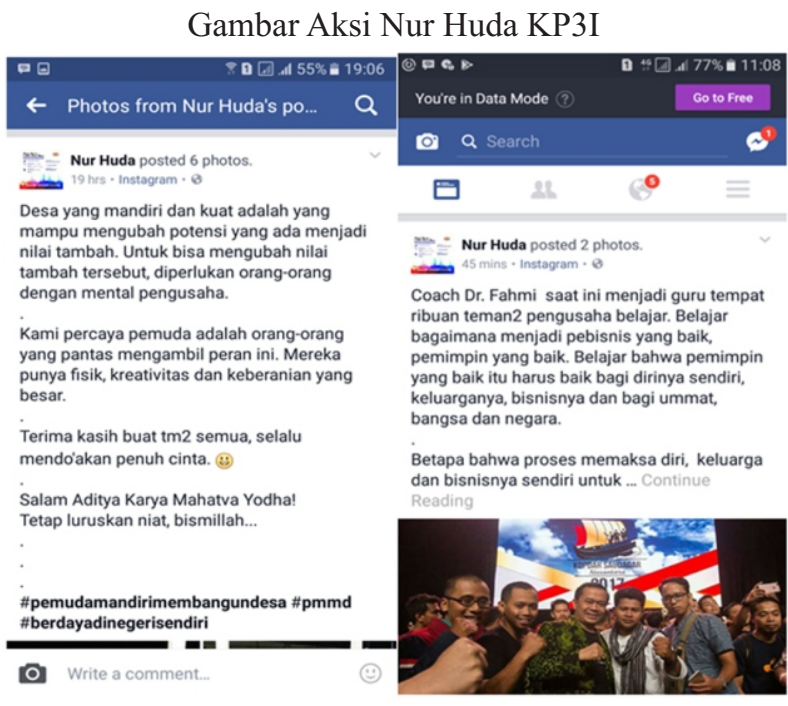

Sumber : Dokumentasi Peneliti di Facebook

Gambar penjelasan komunitas anak bumi dalam program pemberdayaan Agradaya
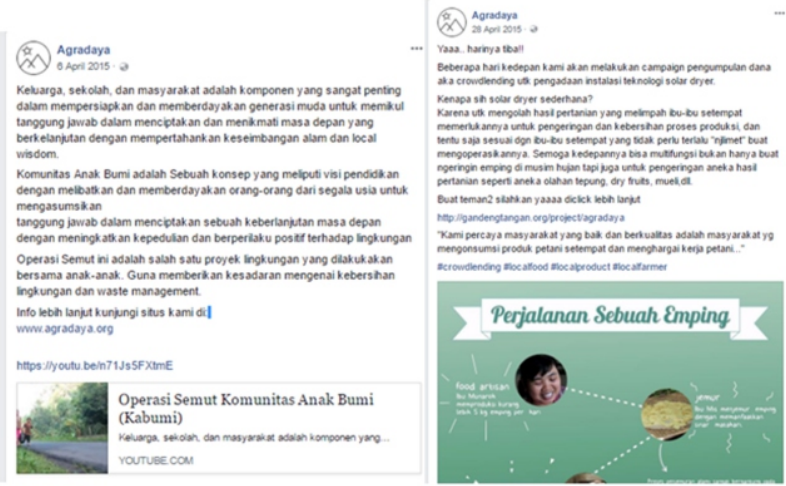

Sumber : Dokumentasi Peneliti

Gambar : Komunitas Ojek Difabel

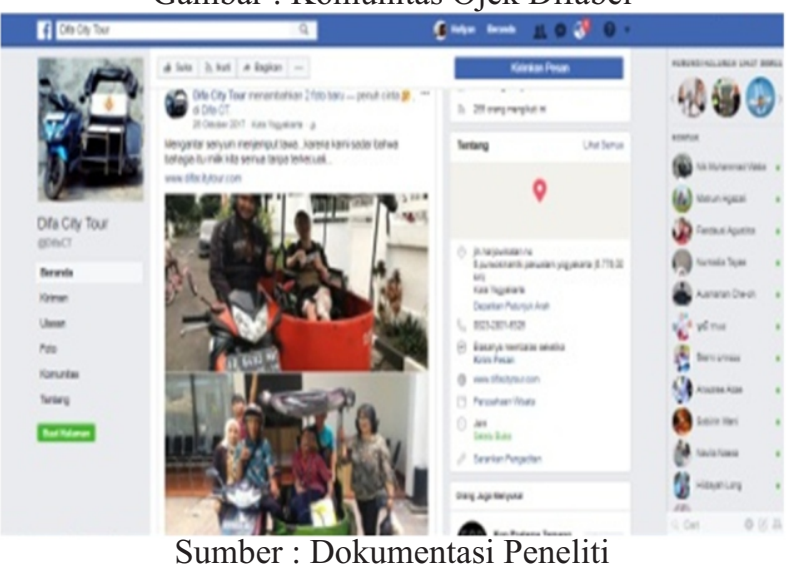

Sumber: Dokumentasi Peneliti
Dari contoh screenshot diatas kita bisa melihat bahwa perspektif hyperpersonal Walther berlaku disini. Contoh diatas menggambarkan "bagaimana pengirim memilih, penerima memperluas, mempromosikan saluran, dan umpan balik meningkatkan perilaku komunikasi yang selektif dan selektif di CMC". Selain itu terlihat juga bahwa melalui selective self-presentation, orang-orang yang bertemu secara online memiliki kesempatan untuk membuat dan mempertahankan impresi yang sangat positif. Walther mengklaim hal itu dapat terjadi karena mereka dapat menulis tentang sifat, pencapaian, pemikiran, dan tindakan mereka yang paling menarik tanpa takut kontradiksi dari penampilan fisik mereka, tindakan mereka yang tidak konsisten, atau keberatan pihak ketiga yang mengetahui sisi gelap mereka. Social Information Processing mengungkapkan ketika komunikator diizinkan untuk bertukar pesan, maka hubungan interpersonal mereka akan sebanding dengan yang dihasilkan dalam komunikasi tatap muka. Hubungan ini merupakan hasil dari timbulnya kesan positif dari penerima.

Jika ditelaah, yang dilakukan young social entrepreneurs di facebook bukan hanya penyertaan foto dan video, tapi juga kemampuan untuk membuat profil pribadi, membangun koneksi jaringan dan menambahkan informasi ke orang lain. Saat pengguna mengunggah informasi tentang kegiatan mereka, pengguna lain dapat menambahkan, atau bahkan mengkontraskan 
informasi itu. Bagi pengguna Facebook, informasi tambahan semacam itu sangat mungkin dilakukan, mulai dari komentar berbasis teks pada konten hingga tautan ke foto dan video. Dengan kata lain, situs seperti Facebook menampilkan dua jenis informasi yang dikendalikan oleh pemilik akun dan yang berada di luar kendali langsung pemilik akun. Walther meyakini ini adalah salah satu perbedaan bagaimana pengguna Facebook memproses informasi sosial.

\section{SIMPULAN}

Kota Yogyakarta yang dikenal kota pelajar ini bisa memanfaatkan praktek dan pendidikan social enterpreneurship agar program pembangunan bisa terakselerasi secara cepat. Selain itu permasalahan yang belum terselesaikan oleh pemerintah bisa selesai karena potensi kota yang belum tergarap akan menjadi terlihat. Hal terpenting lainnya adalah menularkan spirit entrepreneurship yang selalu berusaha melihat solusi dari permasalahan yang ada bukannya hanya cenderung berkomentar alih-alih mengkritik dan mencari kambing hitam. Pada era digital seperti sekarang, kekuatan untuk dapat tumbuh dan berkembang bertumpu pada kuantitas dan kualitas jaringan dibanding modal yang lain. Kekuatan suatu organisasi beralih dari yang tampak menjadi tidak tampak, dari fisik ke digital, dan dari organisasi yang berpusat pada suatu perubahan tertentu berubah ke organisasi berbasis jaringan.

\section{REFERENSI}

Al Hafiz, M. W. S. (2016, June). Youth, Women, Netizen. Marketeers.

Ali, H. L. P. (2017). Millennial Nusantara. jakarta: Graedia Puataka Utaman.

Baillet, P. O. C. (2009). Ethnography of Communication in Encyclopedia of Communication.

Dijk, J. Van. (2006). The Network Society. Social Aspects of New Media. The New Faces of Victimhood: Globalization, .... Retrieved from http://www.tlu.ee/ kpata/uusmeedia/The NetworkSociety.pdf

Griffin, E. (2012). Communication :A first Look At Communication Theory. McGraw-Hill.

Hine, C. (Ed.). (2005). Virtual Methods : Issues in Social research on The Internet. New York: Berg, Oxhord.

Hulgard, L. (2010). Discourses of Social Enterpreneurship - Variations of The Same Theme? EMES European Research Network.

Kertajaya, H. (2017). Citizen 4.0. Gramedia Pustaka Utama.

Littlejohn, Stephen W. Foss, K. A. (Ed.). (2009). Encyclopedia of Communication Theory. Sage Publication.

MIX. (2016, September). Pasar E-Commerce Indonesia Terbesar di Asean, 9.

Nasrullah, R. (2014). Teori dan Riset Media Siber. PrenadaMedia Grup. 
Pambudi, S. T. (2017). Dua Pilar Masa Depan

Facebook. SWA, 77.

Scheibel, Dean Eadie. (2009). Qualitative,

Ethnographic, and Performative

Approaches to Communications in $21 \mathrm{st}$

Century Communication, A Reference

Handbook. Sage Publication.

Survey Indonesia E-Commerce 2016. (2016,

November). SWA, 44.

Susanto, E. H. (2010). Media Baru, Kebebasan

Informasi dan Demokrasi di Kalangan

Generasi Muda. Universitas

Tarumanegara Indonesia.

Walther, J. (2012). Social Information

Processing Theory. In Communication

Theory (8th ed., p. 138). McGraw-Hill. 